\section{Calcifying Bacteria: Their Applications}

\section{Swaranjit Singh Cameotra*}

Institute of Microbial Technology, Chandigarh, India

Concrete structures are susceptible to cracking which allows water and damaging chemicals/microbes to enter and degrade the concrete, reducing the strength of the structure as well as requiring costly maintenance and repairs. Therefore, it is worthwhile to develop such bacterial strains which would carry out calcium carbonate precipitation in extreme conditions. Extremophile calcifying bacterial cultures produce urease enzyme which is capable of precipitating calcium in the surrounding micro environment as $\mathrm{CaCO}_{3}$. The bacterial degradation of urea locally increases the $\mathrm{pH}$ and promotes the microbial deposition of carbonate. These precipitated crystals can thus fill the cracks and enhance the durability of the concrete. The generation of 'bio-concrete' by incorporating very specific extremophiles calcifying bacteria will be helpful for developing a self healing material or "bio-cementing" technology.

The Calcifying bacteria can be isolated from different sources like soil, hot water springs, ocean, alkaline environment or the cement itself. The purified strains can be grown for $24 \mathrm{~h}$ in the lab and then mixed with the concrete for application. It would facilitate the microbes to grow in the system if some cheap carbon source like molasses/glycerol is added to the mixture. The behavior of these added microbes has to be studied in mortar cubes and beams after the curing time of 28 days. After this period the tensile strength, micro-crack healing capacity and durability has to be studied along with the condition of the added microbes using Electron microscopy, XRD analysis and water permeability.

This interesting phenomenon is gaining a lot of attention currently around the globe. The healing and sealing activity of microbes has a variety of applications like conservation of monuments by applying it as a coating along with maintenance mixtures. The active microbes seep

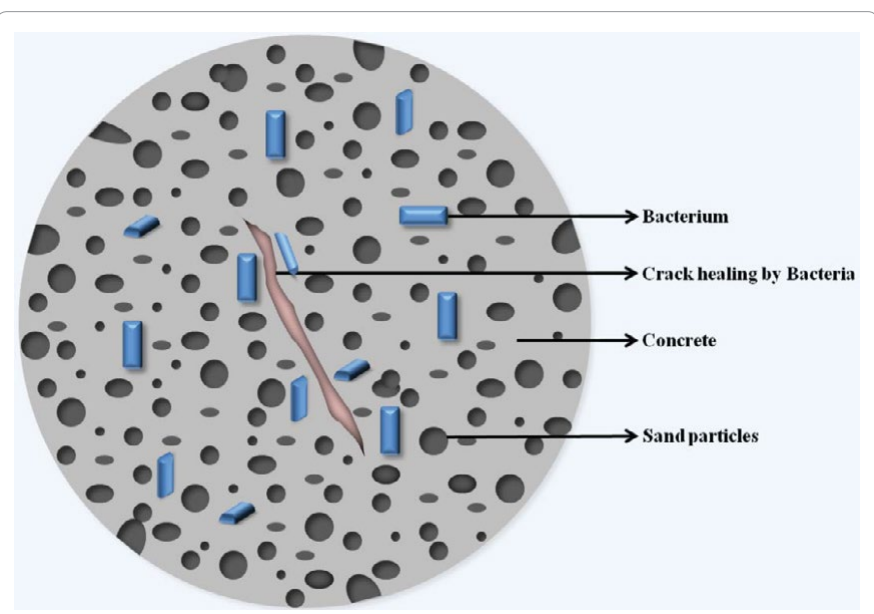

Figure 1: Calcifying Bacteria and their applications

in through the cracks and micro-pits and bio-cement the micro-cracks by producing the calcifying precipitate in the structure. The other application is in bio-concrete structures like buildings. The process is a combination of biology and civil engineering disciplines. This can be extended to bridges and roads.

The process using microbes is a green and eco-friendly way of:

I Conservation of concrete material and maintaining its strength and durability

II Bio-healing and sealing of concrete micro-cracks.
"Corresponding author: Swaranjit Singh Cameotra, Institute of Microbial Technology, Chandigarh, India, Tel: +91-172-6665233, E-mail: ssc@imtech.res.in

Receive May 17, 2016; Accepted May 19, 2016; Published May 25, 2016

Citation: Cameotra SS (2016) Calcifying Bacteria: Their Applications. J Pet Environ Biotechnol 7: e127. doi:10.4172/2157-7463.1000e127

Copyright: () 2016 Cameotra SS. This is an open-access article distributed under the terms of the Creative Commons Attribution License, which permits unrestricted use, distribution, and reproduction in any medium, provided the original author and source are credited. 